\title{
Teaching Video NeuroImages: Cluster Breathing in Brainstem-Sparing Bihemispheric Cerebral and Cerebellar Lesions
}

Roger M. Meza, MD, Hans Schulz, MD, Diego Alva, MD, and Alberto J. Espay, MD, MSc

Neurology ${ }^{\circledR}$ 2021;96:e2243-e2244. doi:10.1212/WNL.0000000000011215

Figure Brain MRI and Monitoring Screen

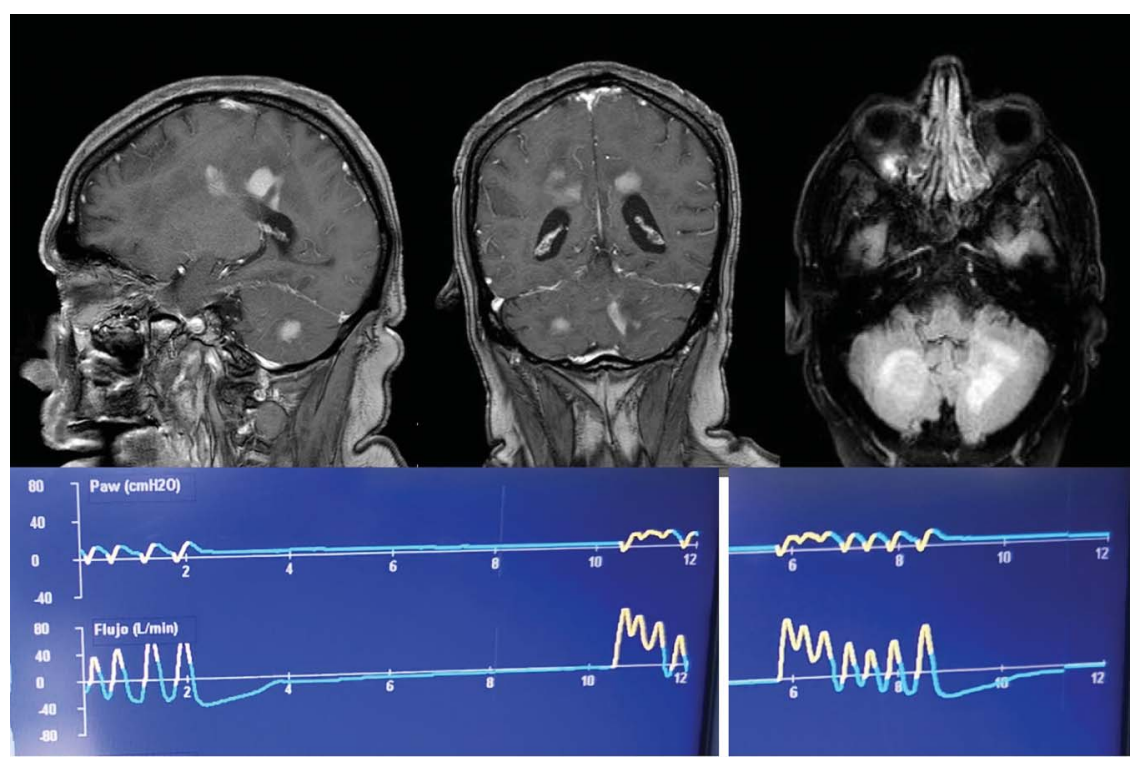

Postcontrast sagittal and coronal T1-weighted brain MRI demonstrated nodular bihemispheric lesions as well as contrast-enhancing bilateral cerebellar lesions with no mass effect on the brainstem. Screenshots of the respiratory monitor at the bottom document the cluster-breathing waveforms in the mean airway pressure $\left(\mathrm{Paw}\right.$, in $\left.\mathrm{cm} \mathrm{H}_{2} \mathrm{O}\right)$ and volume (flow, in L/min).

A 65-year-old comatose man with metastatic melanoma developed rapidly cycling breathing, with clusters of approximately 10 abdominal excursions within 3 seconds, interspersed by 10 seconds of apnea (video 1 and figure), mimicking abdominal myoclonus. Introduced by Plum and Posner ${ }^{1}$ as a respiratory pattern associated with lesions in the low pons or high medulla, cluster breathing can occur without pontomedullary lesions when respiratory alkalosis accompanies bihemispheric lesions. ${ }^{2}$ It differs from the constant tachypnea of central neurogenic hyperventilation, also associated with respiratory alkalosis, and from the crescendodecrescendo breathing pattern of Cheyne-Stokes. Combined cerebellar and cerebral lesions may suffice to affect brainstem-mediated respiratory control in the absence of brainstem lesions.

\section{Correspondence}

Dr. Espay

alberto.espay@uc.edu

\section{MORE ONLINE}

- Video

$\rightarrow$ Teaching slides

links.lww.com/WNL/

B277

\section{Study Funding}

No targeted funding reported. 


\section{Disclosure}

R.M. Meza, H. Schulz, and D. Alva report no disclosures. A.J. Espay has received grant support from the NIH and the Michael J Fox Foundation; personal compensation as a consultant/ scientific advisory board member for AbbVie, Neuroderm, Neurocrine, Amneal, Adamas, Acadia, Acorda, InTrance, Sunovion, Lundbeck, and USWorldMeds; publishing royalties from Lippincott Williams \& Wilkins, Cambridge University Press, and Springer; and honoraria from USWorldMeds, Acadia, and Sunovion. Go to Neurology.org/N for full disclosures.

\section{Appendix Authors}

\begin{tabular}{lll}
\hline Name & Location & Contribution \\
\hline $\begin{array}{l}\text { Roger M. } \\
\text { Meza, MD }\end{array}$ & $\begin{array}{l}\text { Hospital Regional } \\
\text { Docente de Trujillo, } \\
\text { Peru }\end{array}$ & $\begin{array}{l}\text { Evaluation of patient, drafted the } \\
\text { manuscript for intellectual } \\
\text { content }\end{array}$ \\
\hline
\end{tabular}

Appendix (continued)

\begin{tabular}{lll}
\hline Name & Location & Contribution \\
\hline $\begin{array}{l}\text { Hans } \\
\text { Schulz, MD }\end{array}$ & $\begin{array}{l}\text { Hospital Regional } \\
\text { Docente de Trujillo, } \\
\text { Peru }\end{array}$ & $\begin{array}{l}\text { Major role in the acquisition of } \\
\text { data, review of manuscript }\end{array}$ \\
\hline $\begin{array}{l}\text { Diego Alva, } \\
\text { MD }\end{array}$ & $\begin{array}{l}\text { Hospital Regional } \\
\text { Docente de Trujillo, } \\
\text { Peru }\end{array}$ & $\begin{array}{l}\text { Major role in the acquisition of } \\
\text { data, review of manuscript }\end{array}$ \\
\hline $\begin{array}{l}\text { Alberto J. } \\
\text { Espay, MD, } \\
\text { MSc }\end{array}$ & $\begin{array}{l}\text { University of } \\
\text { Cincinnati, OH }\end{array}$ & $\begin{array}{l}\text { Critical review of manuscript, } \\
\text { supervise all review cycles }\end{array}$ \\
\hline
\end{tabular}

\section{References}

1. Plum F, Posner JB. The Diagnosis of Stupor and Coma. New York: Oxford University Press; 1982.

2. Freeman WD, Sen S, Roy TK, Wijdicks EF. Cluster breathing associated with bihemispheric infarction and sparing of the brainstem. Arch Neurol 2006;63: $1487-1490$. 


\section{Neurology}

\section{Teaching Video NeuroImages: Cluster Breathing in Brainstem-Sparing Bihemispheric Cerebral and Cerebellar Lesions}

Roger M. Meza, Hans Schulz, Diego Alva, et al.

Neurology 2021;96;e2243-e2244 Published Online before print November 16, 2020

DOI 10.1212/WNL.0000000000011215

This information is current as of November 16, 2020

Updated Information \&

Services

References

Subspecialty Collections

Permissions \& Licensing

Reprints including high resolution figures, can be found at: http://n.neurology.org/content/96/17/e2243.full

This article cites 1 articles, 0 of which you can access for free at: http://n.neurology.org/content/96/17/e2243.full\#ref-list-1

This article, along with others on similar topics, appears in the following collection(s):

All Clinical Neurology

http://n.neurology.org/cgi/collection/all_clinical_neurology

Coma

http://n.neurology.org/cgi/collection/coma

Critical care

http://n.neurology.org/cgi/collection/critical_care

Prognosis

http://n.neurology.org/cgi/collection/prognosis

Information about reproducing this article in parts (figures,tables) or in its entirety can be found online at:

http://www.neurology.org/about/about_the_journal\#permissions

Information about ordering reprints can be found online:

http://n.neurology.org/subscribers/advertise

Neurology ${ }^{\circledR}$ is the official journal of the American Academy of Neurology. Published continuously since 1951, it is now a weekly with 48 issues per year. Copyright @ 2020 American Academy of Neurology. All rights reserved. Print ISSN: 0028-3878. Online ISSN: 1526-632X.

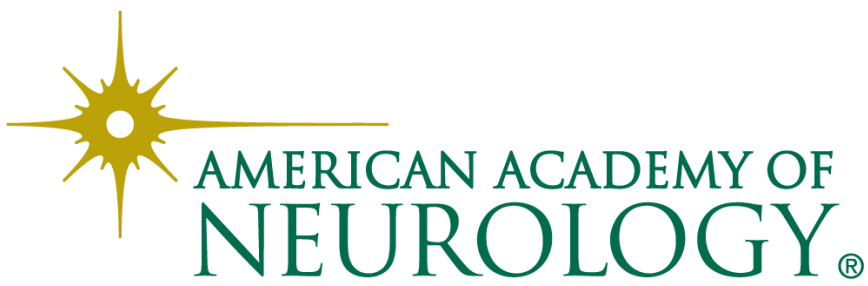

